\title{
Optimization of Medium Composition for Enhancing Growth of Lactobacillus rhamnosus PEN Using Response Surface Methodology
}

\author{
MAGDALENA POLAK-BERECKA ${ }^{1 *}$, ADAM WAŚKO ${ }^{1}$, MONIKA KORDOWSKA-WIATER $^{1}$, \\ MARCIN PODLEŚNY ${ }^{1}$, ZDZISŁAW TARGOŃSKI ${ }^{1}$ and AGNIESZKA KUBIK-KOMAR ${ }^{2}$ \\ ${ }^{1}$ Department of Biotechnology, Human Nutrition and Science of Food Commodities \\ ${ }^{2}$ Department of Applied Mathematics and Computer Science, University of Life Sciences in Lublin, \\ Lublin, Poland
}

Received 14 September 2009, revised 5 January 2010, accepted 3 February 2010

\author{
Abstract
}

Response surface methodology was used to optimize media components such as carbon and nitrogen (simple and complex) sources, mineral agents and growth factors (B vitamins, amino acids) for enhancing the biomass production of Lactobacillus rhamnosus PEN. For screening experiment the following carbon sources were selected: glucose, glucose+pyruvate, glucose+citrate, glucose+lactate, galactose, fructose, lactose, sucrose, maltose, lactulose, fructooligosaccharides, maltodextrins DP 4-7 and DP 13-17. Nitrogen sources such as yeast extract, meat extract and peptone $\mathrm{K}$ were used in lower concentrations than in MRS medium which served as a control. All experiments were run at $37^{\circ} 3 \mathrm{C}$ for $24-48 \mathrm{~h}$ under stationary conditions. Constituents chosen after the first screening experiments were further screened by the Plackett-Burman design. Glucose and sodium pyruvate, meat extract, potassium phosphate, sodium acetate, and ammonium citrate were chosen as promising medium components for further optimization studies. By solving the regression equation and analyzing the response surface carton, optimal concentrations of the components were determined as: glucose $(13.4 \mathrm{~g} / 1)$, sodium pyruvate $(3.4 \mathrm{~g} / \mathrm{l})$, meat extract $(7.2 \mathrm{~g} / \mathrm{l})$, potassium phosphate $(2.0 \mathrm{~g} / \mathrm{l})$, sodium acetate $(5.0 \mathrm{~g} / \mathrm{l})$ and ammonium citrate $(2.0 \mathrm{~g} / \mathrm{l})$. In comparison to MRS broth the optimal medium contained fewer ingredients and in modified amounts but $L b$. rhamnosus PEN showed better growth activity. Biomass concentration (as dry cell weight) of bacteria cultivated in optimal medium at bioreactor conditions was $5.5 \mathrm{~g} / \mathrm{l}$ after $16 \mathrm{~h}$ of incubation, being higher in comparison with bacterial growth in MRS medium (1.9 g/l) under the same conditions. Moreover, the new medium was less expensive.

Ke y words: Lactobacillus, biomass, growth, optimization

\section{Introduction}

Lactic acid bacteria are commercially important in many branches of industry e.g. pharmaceutical and food industry as dietary supplements and probiotic products. There are many products in the market containing viable LAB (lactic acid bacteria) cells. The primary objective of these products is to achieve persistent colonization of the bacteria in the gut during the treatment of a variety of conditions such as gastrointestinal disorders (e.g. post-antibiotic therapy, adjustment of microbial imbalances in the gut, liver diseases) (Tamime et al., 1995; Grönlund et al., 2000; Guandalini et al., 2000; Gupta and Garg 2009). Their positive effect on human health explains the great interest of scientists in their growth and physiology. As Lactobacilli are fastidious with respect to nutrient requirements, rich medium is required for good growth (Liew et al., 2005). The most common medium for lactic acid bacteria is the Man Rogosa Sharpe medium (MRS) (de Man et al., 1960; Rogosa et al., 1961). However, high growth activity of lactobacilli is affected by medium formulation. In the past, several studies focused on the optimization of the growth medium of dairy strains of Lb. rhamnosus (Liew et al., 2005). Research concerned the influence of various carbon and nitrogen sources, other growth factors (amino acids and vitamins) and culture conditions such as temperature, $\mathrm{pH}$, the level of aeration on bacterial growth. Liew et al. (2005) found that yeast extract, glucose, vitamins and $\mathrm{pH}$ gave higher counts of viable cells than MRS. Another study experimentally verified that co-metabolism of glucose and pyruvate enhances the growth rate of Lb. rhamnosus (Bajpaj-Dikshit et al., 2003).

Response surface methodology (RSM) is commonly used to explore nonlinear relationships between

\footnotetext{
* Corresponding author: M. Polak-Berecka, Department of Biotechnology, Human Nutrition and Science of Food Commodities, University of Life Sciences in Lublin, Skromna 8, 20-704 Lublin, Poland; phone: (+48) 814623 356; fax: (+48) 81 46 23 400; e-mail: 3mj@wp.pl
} 
studied factors and the dependent variables. It also provides information about optimal values of these factors to determine the expected largest (or smallest) values for the dependent variables of interest. This methodology includes factorial design and regression analyses (Xiaobo et. al., 2006) and is commonly preceded by primary screening with the "one-variable-attime" approach or Plackett-Burman design application (Xin et. al., 2005; Preetha et. al., 2007).

Media formulation and optimization are the primary steps involved in bioprocess technology. The aim of our study was to develop a new medium for costeffective production of $L b$. rhamnosus PEN biomass.

\section{Experimental}

\section{Materials and Methods}

Microorganism. A strain of Lb. rhamnosus PEN obtained from Biomed Serum and Vaccine Production Plant Ltd. in Lublin, Poland was used in all experiments.

Culture maintenance and inoculum preparation. Bacteria were stored at $-80^{\circ} \mathrm{C}$ in MRS medium with the addition of $20 \%(\mathrm{v} / \mathrm{v})$ glycerol. The strain was revitalized in MRS broth at $37^{\circ} \mathrm{C}$ for $24 \mathrm{~h}$. After two passages the bacterial culture was used to prepare $24 \mathrm{~h}$ inoculum in MRS (BTL) medium in the same conditions.

Culture media. a) The influence of different sources of carbon on Lactobacillus growth was tested: glucose $(\mathrm{POCH})$, glucose+sodium pyruvate (Sigma), glucose+ammonium citrate $(\mathrm{POCH})$, glucose + sodium lactate (Sigma), galactose $(\mathrm{POCH})$, fructose $(\mathrm{POCH})$, lactose $(\mathrm{POCH})$, sucrose $(\mathrm{POCH})$, maltose $(\mathrm{POCH})$, lactulose (ICN), fructooligosaccharides (Arnaut), maltodextrins DP 4-7 and DP 13-17 (Sigma). The MRS medium containing each carbon source separately in concentration $20 \mathrm{~g} / 1$ and $\mathrm{pH} 6.2$ was sterilized at $121^{\circ} \mathrm{C}$ for $15 \mathrm{~min}$ in tubes.

b) The influence of optimal concentration of complex nitrogen sources was examined in modified MRS broth, where yeast extract, meat extract and peptone $\mathrm{K}$ were used in lower concentrations than in control medium. The concentrations of nitrogen sources are given in Table I. Media prepared in tubes were pasteurized in an autoclave for $20 \mathrm{~min}$.

c) The influence of amino acids and vitamins from B group on bacteria growth was also investigated. Modified MRS medium concerning $100 \times$ lower concentrations of complex nitrogen sources was supplemented with amino acids: L-proline (Pro), L-serine (Ser), L-valine (Val), L-leucine (Leu), L-isoleucine (Ile), L-histidine (His), L-tryptophan (Trp), L-tyrosine (Tyr), L-threonine (Thr), L-methionine (Met), L-glutamic acid (Glu), L-phenylalanine (Phe) (Sigma) in concentration of $0.1 \mathrm{mg} / \mathrm{ml}$ or with vitamins: biotin,
Table I

Concentrations of complex nitrogen sources in modified MRS broth

\begin{tabular}{|l|c|c|c|c|c|c|}
\hline \multirow{2}{*}{$\begin{array}{c}\text { Complex } \\
\text { nitrogen } \\
\text { sources }\end{array}$} & \multicolumn{6}{|c|}{ Dilutions of nitrogen sources in relation to } \\
& $10 \times$ & $25 \times$ & $50 \times$ & $75 \times$ & $100 \times$ & $500 \times$ \\
\cline { 2 - 7 } & \multicolumn{6}{|c|}{ Concentrations $(\mathrm{g} / \mathrm{l})$} \\
\hline Yeast extract & 0.40 & 0.16 & 0.08 & 0.053 & 0.04 & 0.008 \\
\hline Meat extract & 0.80 & 0.32 & 0.16 & 0.107 & 0.08 & 0.016 \\
\hline Peptone K & 1.00 & 0.40 & 0.20 & 0.133 & 0.10 & 0.020 \\
\hline Sum & 2.20 & 0.86 & 0.44 & 0.293 & 0.22 & 0.044 \\
\hline
\end{tabular}

folic acid, nicotinic acid, pantothenic acid, pyridoxal, riboflavin, thiamine, cyanocobalamine (Sigma) in concentration $0.001 \mathrm{mg} / \mathrm{ml}$. The media were pasteurized for $20 \mathrm{~min}$. at $90^{\circ} \mathrm{C}$. The vitamins solutions were filter-sterilized and added to pasteurized cultivation medium prior to inoculation.

Stationary cultures in modified MRS broth and biomass analysis. $10 \mathrm{ml}$ aliquots of medium in tubes were inoculated with bacteria at concentration of $2.5 \%$ $(\mathrm{v} / \mathrm{v})$ and were incubated at $37^{\circ} \mathrm{C}$ for $24-48 \mathrm{~h}$ in relatively anaerobic conditions. Every $2 \mathrm{~h}$ samples were collected and analyzed to determine biomass concentration by optical density measurement (OD). Absorbance was measured at $600 \mathrm{~nm}$ using Biorad spectrophotometer. Biomass was determined using the standard curve of $\mathrm{OD}_{600}$ against dry cell weight.

Verification of statistical model in stationary conditions. On the basis of results obtained in statistical analysis, the optimal medium was composed. It contained glucose $(13.4 \mathrm{~g} / \mathrm{l})$, sodium pyruvate $(3.4 \mathrm{~g} / \mathrm{l})$, meat extract $(7.2 \mathrm{~g} / \mathrm{l})$, potassium phosphate $(2.0 \mathrm{~g} / \mathrm{l})$, sodium acetate $(5.0 \mathrm{~g} / \mathrm{l})$ and ammonium citrate $(2.0 \mathrm{~g} / \mathrm{l}) .10 \mathrm{ml}$ of the medium was pasteurized in tubes at $90^{\circ} \mathrm{C}$ for $20 \mathrm{~min}$ and then inoculated with Lactobacillus strain $(2.5 \% \mathrm{v} / \mathrm{v})$. Incubation in relatively anaerobic conditions was continued at $37^{\circ} \mathrm{C}$ for $24 \mathrm{~h}$. After $16 \mathrm{~h}$ samples were collected to determine biomass concentration. This was done in triplicate.

Influence of $\mathrm{pH}$ on bacterial growth in bioreactor conditions. Comparison of Lactobacillus growth in optimal and MRS media. Cultures of Lb. rhamnosus PEN were run in bioreactor in medium composed on the basis of statistical analysis. $\mathrm{pH}$ was adjusted to 4.5, 5.0, 5.5 and 6.0 and was maintained at right level using $30 \% \mathrm{NaOH}$. Working volume was $500 \mathrm{ml}$ in 11 vessel with stirring $100 \mathrm{rpm}$. The medium was inoculated with $2 \%(\mathrm{v} / \mathrm{v})$ of $12 \mathrm{~h}$ bacterial culture. Incubation temperature and time were $37^{\circ} \mathrm{C}$ (water bath) and $24 \mathrm{~h}$, respectively. Cultures were run in relatively anaerobic conditions and every $2 \mathrm{~h}$ samples were collected for biomass analysis. For comparison study with MRS broth optimal medium with $\mathrm{pH} 6.0$ was chosen and the remaining culture conditions and parameters were as above. 
Statistical optimization. The Plackett-Burmann design is a very useful tool that enables us to screen $n$ variables using only $n+1$ experiments (Myers and Montgomery, 1995). It was applied to limit the considerate number of media. Then the central composite design was used to estimate response surfaces, following the general model equation:

$$
Y=\beta_{0}+\sum \beta_{i} X_{i}+\sum \beta_{i l} X_{i}^{2}+\sum \beta_{i j} X_{i} X_{j}
$$

where $Y$ represents response variable, $\beta_{0}$ is the interception, $\beta_{i}$ - linear effect, $\beta_{i i}$ - quadratic effect and $\beta_{i j}$ - interaction effect coefficients. $X_{i}, X_{j}$ are coded values of the factors chosen as the result of the Plackett-Burman design analysis.

The significance of the obtained model was checked by F-test and goodness of fit by multiple correlation $\mathrm{R}$ as well as determination $\mathrm{R}^{2}$ coefficients.

To illustrate the relationships between experimental and predicted values the response surface plots were shown. All design matrices were generated and analyzed using Statistica version 7 software.

\section{Results and Discussion}

Screening experiments. Growth activity of $L$. rhamnosus in media containing different carbon sources resulted in different growth profiles. Table II shows the data for growth of Lb. rhamnosus PEN in the first set of screening experiments. One-variable-at-a-time approach made it possible to point out the highest yield of biomass and the time after which it was achieved when the medium contained a particular carbon source.

Regarding the effect of carbohydrates, Mataragas et al. (2004) reported that glucose concentrations did not improve the total biomass produced by Leuconostoc mesenteroides and Lactobacillus curvatus, whereas Liew et al. (2005) showed a slight effect of glucose on the cell number of Lactobacillus rhamnosus. Our study shows that the yield of biomass was considerably higher when the cells were cultured in glucose + sodium pyruvate as compared to the case when the cells were cultured on glucose alone or other examined carbon sources. Bajpaj-Dikshit et al. (2003) stated that pyruvate is co-metabolized with glucose by Lb. rhamnosus in the medium and the co-metabolism increases the growth rate on glucose 1.4-fold. It appears that among the various carbon sources studied the preferred substrate for Lb. rhamnosus is glucose + pyruvate. In medium containing multiple substrates a typical diauxic growth curve was observed.

In the present study it was observed that Lb. rhamnosus PEN needs complex nitrogen sources and mineral and organic salts at the level of $0.22 \mathrm{~g} / \mathrm{l}$, $2.0 \mathrm{~g} / 1,7.0 \mathrm{~g} / \mathrm{l}$, respectively, for growth. After amino acids supplementation no positive effect on bacterial
Table II

Effect of various carbon sources on growth of L. rhamnosus PEN

\begin{tabular}{|l|c|c|}
\hline \multicolumn{1}{|c|}{ Carbon sources } & $\begin{array}{c}\text { Maximal value } \\
\text { of biomass dry weight } \\
(\mathrm{g} / \mathrm{l} \pm \text { s.d. })\end{array}$ & $\begin{array}{c}\text { Cultivation } \\
\text { time } \\
(\mathrm{h})\end{array}$ \\
\hline Glucose & $5.185 \pm 0.177$ & 20 \\
\hline Fructose & $5.045 \pm 0.215$ & 24 \\
\hline Galactose & $4.947 \pm 0.15$ & 26 \\
\hline Lactulose & $4.034 \pm 0.15$ & 26 \\
\hline Lactose & $5.113 \pm 0.1$ & 28 \\
\hline Saccharose & $1.394 \pm 0.06$ & 24 \\
\hline Maltose & $0.927 \pm 0.037$ & 26 \\
\hline Maltodextrins DP $4-7^{*}$ & $0.616 \pm 0.039$ & 28 \\
\hline Maltodextrins DP $13-17 *$ & $0.749 \pm 0.027$ & 28 \\
\hline Fructooligosaccharides & $1.434 \pm 0.054$ & 26 \\
\hline Glucose + pyruvate & $5.219 \pm 0.146$ & 16 \\
\hline Glucose + lactate & $4.842 \pm 0.114$ & 18 \\
\hline Glucose + citrate & $4.467 \pm 0.416$ & 38 \\
\hline
\end{tabular}

* degree of polymerization

growth was observed. Analyzed vitamins did not sufficiently influence the growth of the examined bacteria. Data obtained were used for design of response surface methodology.

Plackett-Burman design. Central composite design. Medium components chosen at the first screening experiments were further screened by the Plackett-Burman design consisting of 8 experiments. The results of the Plackett-Burman design analysis are presented in Table III with estimation values of factors effect (Table IV).

The yield of biomass was mostly influenced by an increase in the concentration of glucose + sodium pyruvate. The positive effect of yeast extract, organic and inorganic salts (potassium phosphate, sodium acetate, ammonium citrate), meat extract and peptone $\mathrm{K}$ was very similar. The increase of $\mathrm{NaCl}$ as well as, to a lesser extent, microelements had a negative effect on biomass production.

Despite the fact that yeast extract is used in most fermentation studies as a supplement, we decided to exclude it from further analysis because meat extract gave a slightly higher yield of biomass (Table IV). Moreover, meat extract contains greater amount of total nitrogen $(12 \% \mathrm{w} / \mathrm{w})$ than YE $(10 \% \mathrm{w} / \mathrm{w})$ (Fung et al., 2008). Some authors studied the effect of less expensive nitrogen sources such as peptone and malt sprouts. They reported that yeast extract and peptone affect the cell concentration significantly (Manteagudo et al., 1995; Hujanen and Linko, 1996). Fung et al. (2008) showed that meat extract, vegetable extract and peptone significantly influenced the growth of Lactobacillus acidophilus.

Because some authors recommended adding ammonium salts (Heriban et al., 1993; Zayed and Winter, 1995) and citrate (Amrane and Prigent, 1998) into the 
Table III

Plackett-Burman design for seven variables

\begin{tabular}{|c|c|c|c|c|c|c|c|c|}
\hline Run & $\begin{array}{c}\text { Glucose } \\
+\begin{array}{c}\text { pyruvate } \\
(\mathrm{g} / \mathrm{l})\end{array}\end{array}$ & $\begin{array}{c}\text { Pepton K } \\
(\mathrm{g} / \mathrm{l})\end{array}$ & $\begin{array}{c}\text { Meat } \\
\text { extract } \\
(\mathrm{g} / \mathrm{l})\end{array}$ & $\begin{array}{c}\text { Yeast } \\
\text { extract } \\
(\mathrm{g} / \mathrm{l})\end{array}$ & $\begin{array}{c}\text { Organic and } \\
\text { inorganic salts } \\
(\mathrm{g} / \mathrm{l})\end{array}$ & $\begin{array}{c}\text { Microelements } \\
(\mathrm{g} / \mathrm{l})\end{array}$ & $\begin{array}{c}\text { NaCl } \\
(\mathrm{g} / \mathrm{l})\end{array}$ & $\begin{array}{c}\text { Biomass } \\
(\mathrm{g} / \mathrm{l})\end{array}$ \\
\hline 1 & 0.26 & 0.20 & 0.16 & 4.00 & 9.00 & 0.238 & 0.00 & 1.005 \\
\hline 2 & 20.00 & 0.20 & 0.16 & 0.08 & 0.90 & 0.238 & 30.00 & 1.229 \\
\hline 3 & 0.26 & 10.00 & 0.16 & 0.08 & 9.00 & 0.0238 & 30.00 & 0.445 \\
\hline 4 & 20.00 & 10.00 & 0.16 & 4.00 & 0.90 & 0.0238 & 0.00 & 3.059 \\
\hline 5 & 0.26 & 0.20 & 8.00 & 4.00 & 0.90 & 0.0238 & 30.00 & 0.691 \\
\hline 6 & 20.00 & 0.20 & 8.00 & 0.08 & 9.00 & 0.0238 & 0.00 & 5.202 \\
\hline 7 & 0.26 & 10.00 & 8.00 & 0.08 & 0.90 & 0.238 & 0.00 & 1.009 \\
\hline 8 & 20.00 & 10.00 & 8.00 & 4.00 & 9.00 & 0.238 & 30.00 & 3.587 \\
\hline
\end{tabular}

Table IV

Variables investigated in the Plackett-Burman design

\begin{tabular}{|l|c|}
\hline \multicolumn{1}{|c|}{ Medium } & Effect Estimate \\
\hline Glucose + pyruvate & 5.322 \\
\hline Peptone $\mathrm{K}$ & 1.426 \\
\hline Yeast extract & 1.505 \\
\hline Meat extract & 1.720 \\
\hline Organic and inorganic salts & 1.536 \\
\hline Microelements & -0.978 \\
\hline $\mathrm{NaCl}$ & -1.571 \\
\hline
\end{tabular}

Table V

Central composite design matrix of the variables along with the experimental values of biomass

\begin{tabular}{|c|c|c|c|c|}
\hline Run & $\begin{array}{c}\text { Glucose }+ \\
\text { pyruvate }\left(\mathrm{X}_{1}\right) \\
(\mathrm{g} / \mathrm{l})\end{array}$ & $\begin{array}{c}\text { Meat } \\
\text { extract }\left(\mathrm{X}_{2}\right) \\
(\mathrm{g} / \mathrm{l})\end{array}$ & $\begin{array}{c}\text { Organic and } \\
\text { inorganic salts } \\
\left(\mathrm{X}_{3}\right)(\mathrm{g} / \mathrm{l})\end{array}$ & $\begin{array}{c}\text { Biomass } \\
(\mathrm{g} / \mathrm{l})\end{array}$ \\
\hline 1 & 0.80 & 0.16 & 0.90 & 1.075 \\
\hline 2 & 0.80 & 0.16 & 9.00 & 0.925 \\
\hline 3 & 0.80 & 8.00 & 0.90 & 1.489 \\
\hline 4 & 0.80 & 8.00 & 9.00 & 1.402 \\
\hline 5 & 20.00 & 0.16 & 0.90 & 1.664 \\
\hline 6 & 20.00 & 0.16 & 9.00 & 1.497 \\
\hline 7 & 20.00 & 8.00 & 0.90 & 3.595 \\
\hline 8 & 20.00 & 8.00 & 9.00 & 4.168 \\
\hline 9 & 0.00 & 4.08 & 4.95 & 0.815 \\
\hline 10 & 26.53 & 4.08 & 4.95 & 3.043 \\
\hline 11 & 10.40 & 0.00 & 4.95 & 0.742 \\
\hline 12 & 10.40 & 10.66 & 4.95 & 3.661 \\
\hline 13 & 10.40 & 4.08 & 0.00 & 3.220 \\
\hline 14 & 10.40 & 4.08 & 11.75 & 4.007 \\
\hline 15 & 10.40 & 4.08 & 4.95 & 4.250 \\
\hline 16 & 10.40 & 4.08 & 4.95 & 4.224 \\
\hline 17 & 10.40 & 4.08 & 4.95 & 4.131 \\
\hline 18 & 10.40 & 4.08 & 4.95 & 4.208 \\
\hline 19 & 10.40 & 4.08 & 4.95 & 4.423 \\
\hline 20 & 10.40 & 4.08 & 4.95 & 4.093 \\
\hline
\end{tabular}

medium as they increased the yield of biomass production, organic and inorganic salts were selected for further analysis as the third variable in Central Composite Design.
For these components the full-factorial CCD of RSM was applied to maximize biomass production. This design consisted of five levels - low and high levels, central point and star points with $\alpha= \pm 1.68$. Since the fact that some values of the star points would have been negative the minimum value for the chosen variables assumed to be zero (Preetha et al., 2006). The design and observed values of biomass are presented in Table V.

The following quadratic regression function was obtained as a result of the CCD analysis:

$$
\begin{aligned}
& Y=0.235316+0.269392 X_{1}-0.011086 X_{1}^{2}+ \\
& 0.534897 X_{2}-0.055169 X_{2}^{2}+0.059668 X_{3}- \\
& 0.007731 X_{3}^{2}+0.012327 X_{1} X_{2}+0.002072 X_{1} X_{3}+ \\
& 0.006323 X_{2} X_{3}
\end{aligned}
$$

where $Y$ is the response value (biomass) and $X_{1}, X_{2}$, $X_{3}$ are coded values of glucose + pyruvate meat extract and organic and inorganic salts, respectively.

The results of ANOVA indicates that the model is statistically significant (Table VI) and the values of

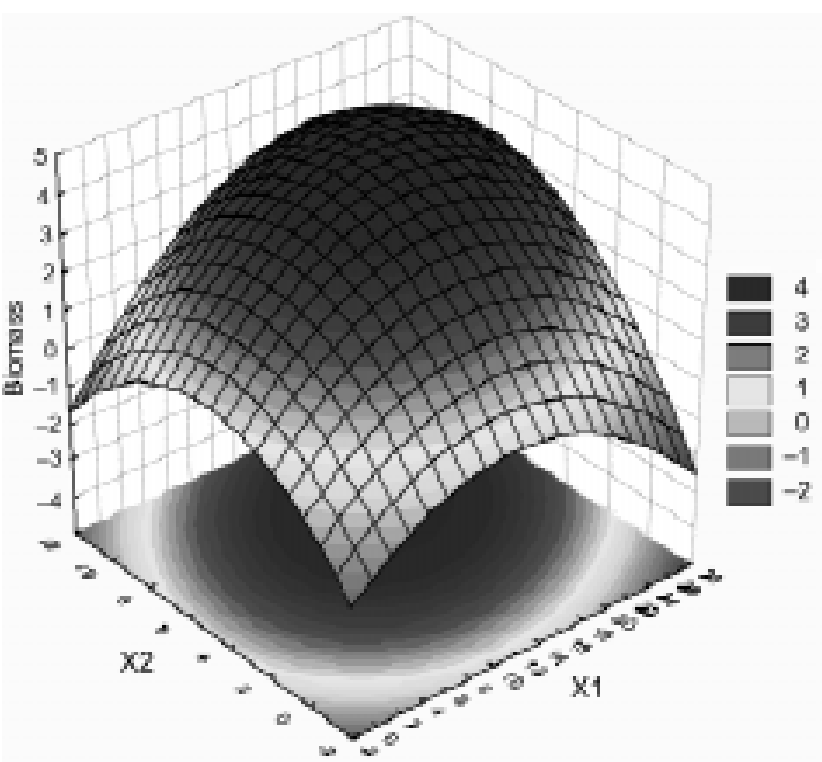

Fig. 1. Effects of glucose + pyruvate $\left(X_{1}\right)$ and meat extract $\left(X_{2}\right)$ on biomass $(\mathrm{g} / \mathrm{l})$ production $(Y)$ with organic and inorganic salts $\left(X_{3}\right)$ at its center point level. 


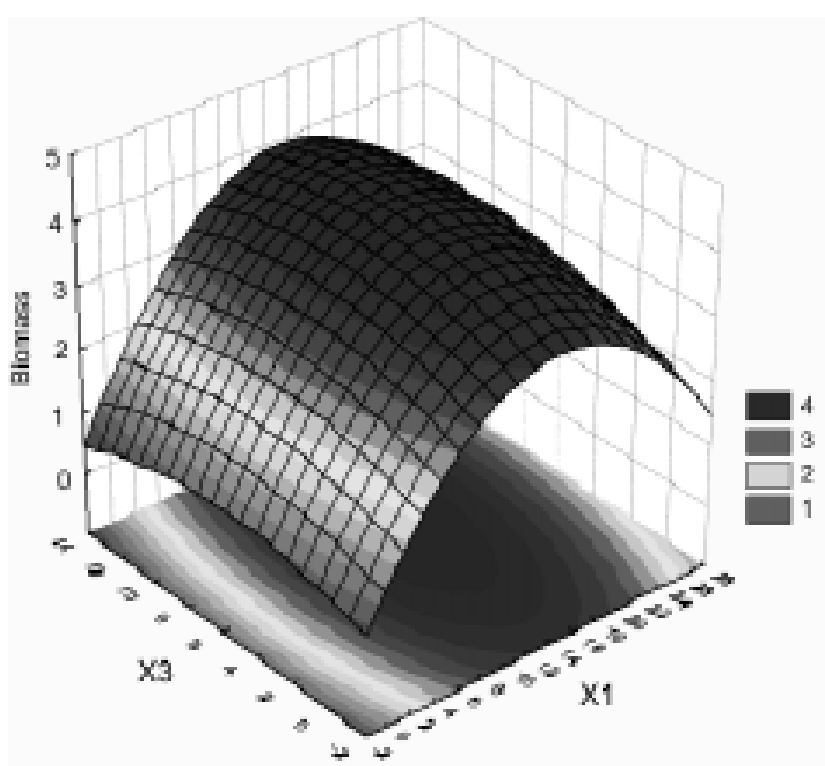

Fig. 2. Effects of glucose + pyruvate $\left(X_{1}\right)$ and organic and inorganic salts $\left(X_{3}\right)$ on biomass $(\mathrm{g} / \mathrm{l})$ production $(Y)$ with meat extract $\left(X_{2}\right)$ at its center point level.

$\mathrm{R}=0.94$ and $\mathrm{R}^{2}=0.88$ that it is also good fitted to the experimental data and explains $88 \%$ of the whole variation of the response. The 3-D response surface plots are shown in Figures 1-3.

As presented above, biomass production is mainly influenced by glucose + pyruvate and meat extract. Based on the regression equation the optimum values of studied ingredients for biomass production, in the low-high level interval, were as follows: glucose + sodium pyruvate $-16.8 \mathrm{~g} / \mathrm{l}$, meat extract $-7.2 \mathrm{~g} / \mathrm{l}$ and organic and inorganic salts $-9 \mathrm{~g} / \mathrm{l}$.

Sodium acetate is reported to enhance the growth of the microorganisms (Peters and Snell, 1954).

Verification of the model in bioreactor conditions. In the present study it was observed that maintenance of $\mathrm{pH}$ at the constant level is important for biomass production by Lb. rhamnosus PEN. The optimum $\mathrm{pH}$ for growth of this strain is 6.0 , what is illus-

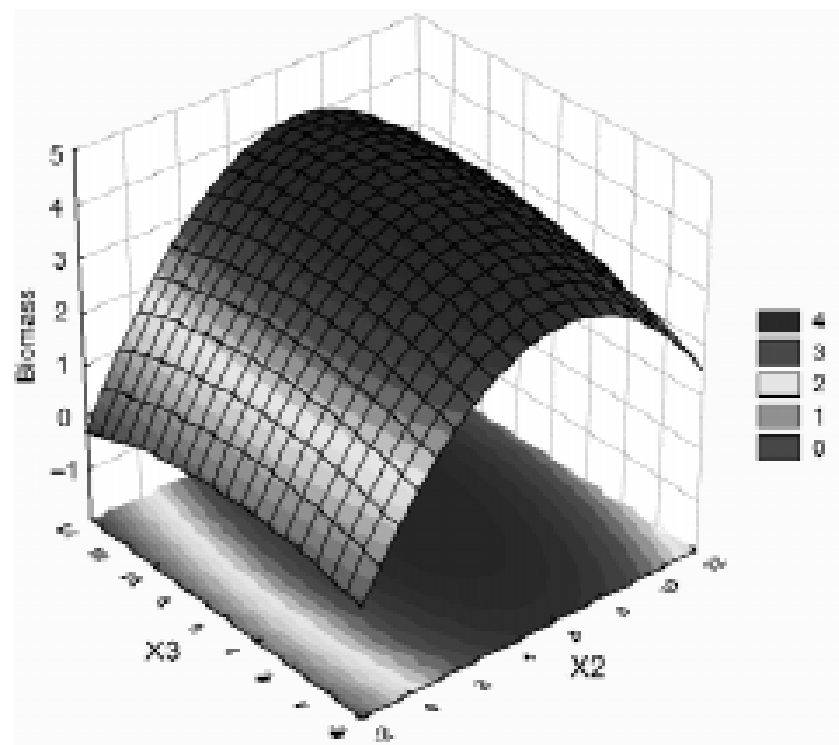

Fig. 3. Effects of meat extract $\left(X_{2}\right)$ and organic and inorganic salts $\left(X_{3}\right)$ on biomass $(\mathrm{g} / \mathrm{l})$ production $(Y)$ with glucose + pyruvate $\left(X_{1}\right)$ at its center point level.

Table VI

Analysis of variance for the current regression model

\begin{tabular}{|l|c|c|c|c|c|}
\hline $\begin{array}{c}\text { Source } \\
\text { of } \\
\text { variation }\end{array}$ & $\begin{array}{c}\text { Sum } \\
\text { of } \\
\text { square }\end{array}$ & $\begin{array}{c}\text { Degree } \\
\text { of } \\
\text { freedom }\end{array}$ & $\begin{array}{c}\text { Mean } \\
\text { square }\end{array}$ & F-Value & p-Value \\
\hline Model & 33.80618 & 9 & 3.756242 & 8.128217 & 0.001488 \\
\hline Error & 4.621237 & 10 & 0.462124 & & \\
\hline
\end{tabular}

trated in Fig.4. When this $\mathrm{pH}$ value was maintained at the constant level the highest yield of Lactobacillus biomass was obtained on optimal medium. The effect of $\mathrm{pH}$ was also studied by Guyot et al. (2003) with Lactobacillus manihotivorans LMG 18010T that grew actively at $\mathrm{pH} 6.5$.

Figure 5 illustrates the growth of the analyzed strain in control (MRS) and optimal media. Biomass concentration of the bacteria cultivated in optimal medium in
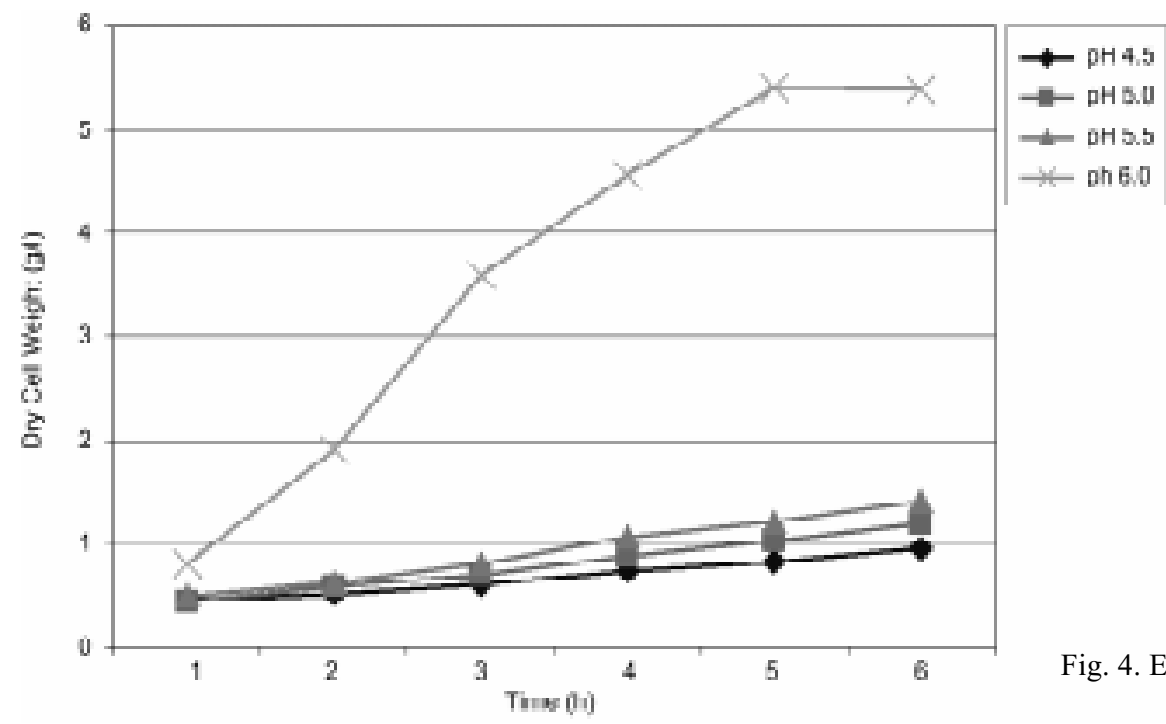

Fig. 4. Effect of $\mathrm{pH}$ on L. rhamnosus PEN growth in optimal medium. 


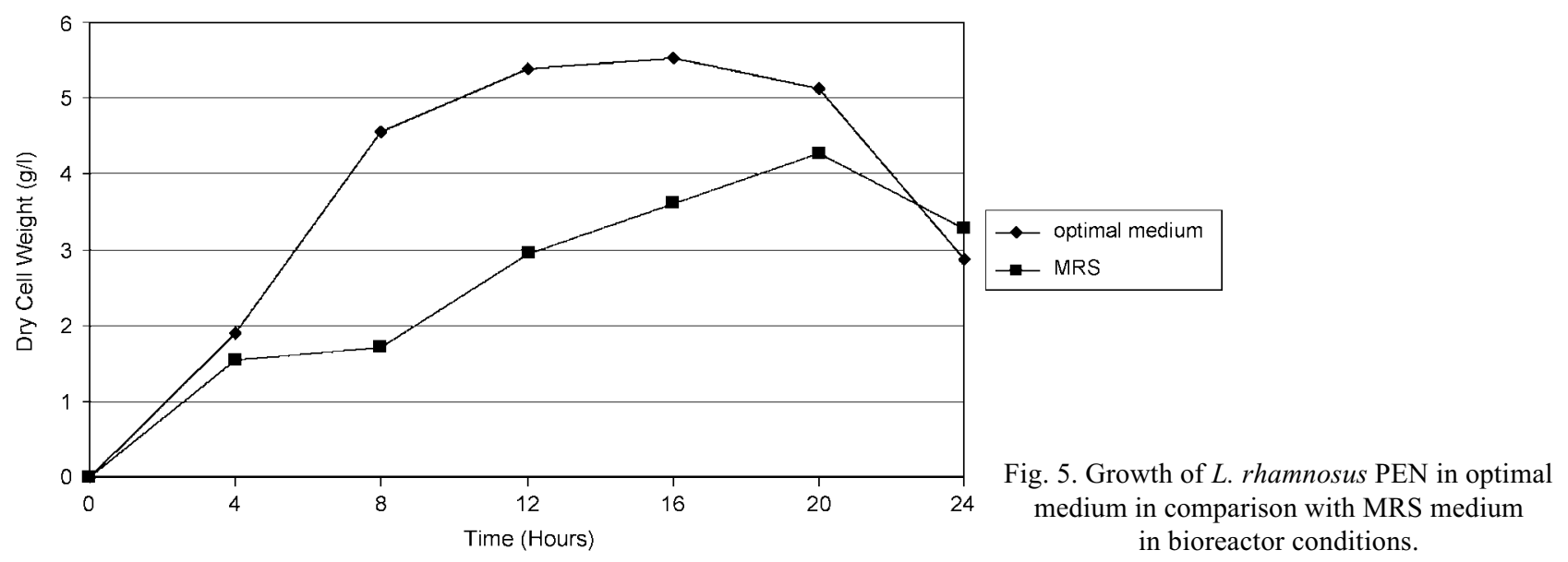

batch culture conditions reached $5.5 \mathrm{~g} / 1$ after $16 \mathrm{~h}$ of incubation, this being higher in comparison with bacterial growth in MRS medium $(1.9 \mathrm{~g} / \mathrm{l})$ under the same conditions. The presented results confirm the usefulness of the new medium for culture of $L b$. rhamnosus PEN on a large scale. Moreover, the new medium is less expensive compared to MRS because 1 liter of new medium costs $€ 6.75$ and 1 liter of MRS broth costs $€ 9.92$ according to our calculation based on SigmaAldrich prices. Taking into consideration the high biomass concentration of the examined Lactobacillus strain and lower costs of the new, optimal medium production there is a possibility of its large scale application.

\section{Acknowledgment}

This study was financially supported by grant R12 06303 from the Polish Ministry of Science and Higher Education.

\section{Literature}

Amrane A. and Y. Prigent. 1998. Influence of yeast extract concentration on batch cultures of Lactobacillus helveticus: growth and production coupling. World J. Microbiol. Biotechnol. 14: 529-534. Bajpaj-Dikshit J., A.K. Suresh and K.V. Venkatesh. 2003. An optimal model for representing the kinetics of growth and product formation by Lactobacillus rhamnosus on multiple substrates. J. Biosci. Bioengin. 96 (5): 481-486.

de Man J.C., M. Rogosa and M.E. Sharpe. 1960. A medium for the cultivation of lactobacilli. J Appl. Microbiol. 23: 130-135.

Fung W.Y., Y.P. Woo and M.T. Liong. 2008. Optimization of growth of Lactobacillus acidophilus FTCC 0291 and evaluation of growth characteristics in soy whey medium: a response surface methodology approach. J. Agric. Food Chem. 56: 7910-7918. Grönlund M.M., Arvilommi H., Kero P., Lehtonen O.P. and Isolauri E. 2000. Importance of intestinal colonisation in the maturation of humoral immunity in early infancy: a prospective follow up study of healthy infants aged 0-6 months. Arch. Dis. Childhood 83: 186-192.

Guandalini S., Pensabene L., Zikri M.A., Dias J.A., Casali J.G., Hoekstra H., Kolacek S., Massar K., Micetic-Turk D., Papadopoulou A., de Sousa J. S., Sandhu B., Szajewska H. and Weizman Z. 2000. Lactobacillus GG administered in oral rehydration solution to children with acute diarrhea: a multicenter European trial. J. Ped. Gastroenterol. Nutr. 30: 54-60.

Gupta V. and Garg R. 2009. Probiotics. Indian Jour. Med. Microbiol. 27 (3): 202-209.
Guyot J.P., M. Calderon and J.M. Guyot. 2003. Effect of pH control on lactic acid fermentation of starch by Lactobacillus manihotivorans LMG18010T. J. Appl. Microbiol. Biotechnol. 105: 637-647.

Heriban V., E. Sturdik, L. Zalibera and P. Matus. 1993. Process and metabolic characteristics of Bacillus coagulans as lactic acid producer. Lett. Appl. Microbiol. 16: 243-246.

Hujanen M. and Y.Y. Linko. 1996. Effect of temperature and various nitrogen sources on $\mathrm{L}(+)$ lactic acid production by Lactobacillus casei. Appl. Microbiol. Biotechnol. 45: 307-313.

Liew S. L., A.B. Ariff, A.R. Raha and Y.W. Ho. 2005. Optimization of medium composition for the production of a probiotic microorganism, Lactobacillus rhamnosus, using response surface methodology. Int. J. Food Microbiol. 102: 137-142.

Manteagudo J.M., J. Rincon, L. Rodriguez, J. Faertes and A. Moya. 1995. Determination of the best nutrient medium for production of $\mathrm{L}$ lactic acid from beet molasses a statistical approach. Acta Biotechnol. 13: 103-110.

Mataragas M., E.H. Drosinos, E. Tsakalidou and J. Metaxopoulos. 2004. Influence of nutrients on growth and bacteriocin production by Leuconostoc mesenteroides L124 and Lactobacillus curvatus L442. Antonie van Leeuwenhoek 85: 191-198.

Myers R.H. and D.C. Montgomery. 1995. Response Surface Methodology. Process and Product Optimization Using Designed Experiments. ed. John Wiley \& Sons Inc., NY.

Peters V.J. and E.E. Snell. 1954. Peptides and bacterial growth. J. Bacteriol. 67: 69-76.

Preetha R., S.N. Jayaprakash, P. Rosamma and I.S. Bright Singh. 2007. Optimization of carbon and nitrogen sources and growth factors for the production of an aquaculture probiotic (Pseudomonas MCCB 103) using response surface methodology. J Appl. Microbiol. 102(4): 1043-1051.

Rogosa M., J.G. Franklin and K.D. Perry. 1961. Correlation of vitamin requirements with cultural and biochemical characters of Lactobacillus subsp. Appl. Microbiol. Biotechnol. 24: 473-482.

Tamime A.Y., V.M. Marshall and R.K. Robinson. 1995. Microbiological and technical aspects of milks fermented by bifidobacteria. J. Dairy Res. 62 (1): 151-187.

Xiaobo Z., W. Haiying, H. Linyu, L. Yongcheng and L. Zhongtao. 2006. Medium optimization of carbon and nitrogen sources for the production of eucalyptene A and xyloketal A from Xylaria sp. 2508 using response surface methodology. Process Biochem. 41(2): 293-298.

Xin C., L. Yin, D. Guocheng and C. Jian. 2005. Application of response surface methodology in medium optimization for spore production of Coniothyrium minitans in solid-state fermentation. World J. Microbiol. Biotechnol. 21: 593-599.

Zayed G. and J. Winter. 1995. Batch and continuous production of lactic acid from salt whey using free and immobilized cultures of lactobacilli. Appl. Microbiol. Biotechnol. 44: 362-366. 